Original Research

\title{
Pollution Assessment of Heavy Metals in Roadside Agricultural Soils
}

\author{
Taiba Ben Seghier ${ }^{1,2}$, Keltoum Bouhadjera ${ }^{1,2}$ \\ ${ }^{1}$ Laboratory of Inorganic Chemistry and Environment, Department of Chemistry, Faculty of Science, \\ Abu BakrBelkaid University, Tlemcen, Algeria \\ ${ }^{2}$ Laboratory of Advanced Materials and Physico-Chemistry for Environment and Health, Department of Chemistry, \\ Faculty of Exact Sciences, University Djillali Liabbes, SBA, Algeria
}

Received: 1 May 2019

Accepted: 8 September 2019

\begin{abstract}
Soil contamination of heavy metals is widespread, raising concerns about agricultural risks. We are investigating the concentrations and forms of the heavy metals lead, zinc, chromium, cobalt, nickel, cadmium and copper in agricultural soils near intensive traffic areas in two major cities in western Algeria: Tlemcen and Sidi Bel Abbes. We analyzed four soil samples cultivated with grapes (E1 and E2) and wheat (E3 and E4). The average concentrations of lead, cadmium, chromium and copper in these agricultural lands exceeded the environmental quality standards of soil in Europe. The average of total concentrations of nickel, cobalt and zinc are less than the environmental quality standards of soil in Europe, which is consistent with the obtained results of the contamination degrees and the potential ecological risk of a single heavy metal. $\left(E_{r}^{i}\right), E_{r}^{i}$ were classified as considerable $\left(80 \leq E_{r}^{i}<160\right)$, high $\left(160 \leq E_{r}{ }^{i}<320\right)$; that, Eir average for $\mathrm{Pb}$ in all soil samples is 68.67 and 162.91 for the $\mathrm{Cd}$. As a result, the ERI of the four soil samples was high in all cases. When using sequential extraction, our results show that cadmium compounds are preferentially concentrated in the carbonate fraction, acid-extractable fraction and residual phase of the soil, causing a risk because of its high value. Co was concentrated in the phases of reducible and oxidizable, while $\mathrm{Pb}, \mathrm{Zn}, \mathrm{Cu}$ and $\mathrm{Ni}$ are highly concentrated in the remaining two remaining phases, which are weak in reducible and oxidizable phases. These results show that these minerals are less readily available in the examined soil. There is also a correlation between nickel-zinc (Ni-Zn), cobalt, zinc (Co-Zn), cadmium and nickel (Cd-Ni), cadmium and chromium (Cd-Cr), cadmium and lead $(\mathrm{Cd}-\mathrm{Pb})$, copper and zinc $(\mathrm{Cu}-\mathrm{Zn})$, and chromium and lead $(\mathrm{Cr}-\mathrm{Pb})$. Soil parameters such as $\mathrm{pH}$, $\mathrm{CEC}, \mathrm{TC} \%$ and organic matter content should also be taken into consideration when determining soil pollution status.
\end{abstract}

Keywords: heavy metals, soil, contamination, sequential extraction, road traffic

*e-mail: hou_da2009@yahoo.fr 


\section{Introduction}

Soil is one of the most valuable non-renewable resources, which at the same time remains among the most severely threatened elements of the natural environment [1]. Soil is also a major source of heavy metals emitted from industrial activities: municipal sewage sludge [2], urban fertilization, road traffic, air sediments and chemicals used in agriculture (phosphate fertilizers and pesticides) have spread to the environment [3]. Heavy metals emitted from stationary and mobile sources can be transported to water, air and soil [4-5], and can even enter plants, animals and human bodies [5-6]. Their initial toxicity and the effects of bioaccumulation [7] have led to many heavy metal emissions being regulated. Heavy metals may cause both human health issues and adverse environmental impacts [8-9]. In addition, heavy metals can accumulate in road dust through atmospheric deposition. Road dust has been used as an indicator of the contamination of heavy metals in our environment [10-11]. Thus, heavy metals may arise from different types of sources. Ground vehicles can release large quantities of heavy metals into the air, water and soil. Therefore, vehicle emissions are a major source of heavy metal pollution in urban environments. Several studies have been completed on the properties of heavy metal concentrations in road dust resulting from traffic activities [12]; there is heavy traffic in many cities in modern society, and the total number of urban vehicles has increased rapidly in modern history [13]. Traffic causes serious problems in large, densely populated cities in particular. Heavy metals from vehicle exhausts, roads, tires and brake wear can be deposited into road dust by dry or wet deposition in the atmosphere [14-16]. In recent years, many materials have concentrated on the concentration and distribution of heavy metals in roadside dust, for example lead, copper, manganese, zinc and Ni have been major environmental contaminants in Turkey and other countries [17-18-19]. Because soil can be a major source of dust and can be a reservoir for dust deposition, it is important to assess the effects of traffic on the distribution and levels of heavy metals in the soil on the roadside. Due to the prolonged use of leaded gasoline in Algeria, the soil can be a reservoir of lead contamination [20].

The objective of this work is therefore to determine the impact of heavy metals on agricultural soils alongside the road linking the cities of Tlemcen and Sidi Bel Abbes through a multidisciplinary approach such as physical-chemical conditions of agricultural soil (in winter) including $\mathrm{pH}$, electrical conductivity, $\mathrm{CEC}$, organic matter and total limestone. Determine the total levels of heavy metals $(\mathrm{Cd}, \mathrm{Cu}, \mathrm{Pb}, \mathrm{Zn}, \mathrm{Ni}, \mathrm{Co}$ and $\mathrm{Cr}$ ) present in agricultural soils by total extraction using a reagent (aqua regia). The contents of heavy metals $(\mathrm{Cd}, \mathrm{Cu}, \mathrm{Pb}, \mathrm{Zn}, \mathrm{Ni}, \mathrm{Co}$ and $\mathrm{Cr})$ present in the soil by selective sequential extraction make it possible to determine the distribution of the heavy metals on the fractions (clays, metal oxides, carbonates, etc.) and identify the soil phases involved in the solubilisation and retention of metal pollutants, and determine the potential environmental risk index for heavy metal and overall environmental risk (ERI), and the correlation between heavy metals in soil.

\section{Material and Methods}

\section{Site Description}

The two sites were selected for this study are located in Sidi Belabbes and Tlemcen, which have a typical Mediterranean climate with precipitation mostly occurring in the autumn and winter and a long summer drought. These sites, planted with wheat and grapes, are located on National Roads $\mathrm{N}^{\circ} 07$ and $\mathrm{N}^{\circ} 39$, which ensures traffic that can affect transport patterns and deposition of car emissions. All locations with similar terrain were large-scale, slightly uneven in traffic flow and provided similar movement patterns.

\section{Soil Analysis}

Samples were taken in winter (2017) during a relatively cold and wet period, but we took a large sampling of the days before the end of winter and early spring 2017 (March). Soil samples were collected from a depth of $\langle 0-30 \mathrm{~cm} »$ from the roadside soil using a stainless steel shovel, away from the road to find the relationship between heavy metal concentration and distance from the road. Soil samples both from plots and from the rhizosphere were dried at $50^{\circ} \mathrm{C}$ until constant weight, homogenized and sieved at $2 \mathrm{~mm}$. The fraction $(2 \mathrm{~mm})$ was characterized for the following: texture (normalized methods for soil analysis, ISS, 1985), $\quad \mathrm{pH}-\mathrm{H}_{2} \mathrm{O}$ (1:2.5 soil:water solution ratio), electrical conductivity (1:5 soil:water solution ratio -Conductimeter basic 30, Crison), carbonate content (Bernard calcimeter method, Loeppert and Suarez, 1996) and ETM concentrations (acid digestion with aqua regia [21] followed by ICP-MS).

The potentially bioavailable fraction of ETM was estimated by a single extraction with a $0.01 \mathrm{M}$ calcium chloride $\mathrm{CaCl}_{2}(1: 10(\mathrm{~W} / \mathrm{V})$ soil/solution ratio, solution adjusted to $\mathrm{pH}<2$ [22]. Heavy metals mobility was estimated by sequential extraction developed by the Standard Measurement and Testing Program of the European Community [23] and applied to differentiate metal fractions in the soils. ETM concentration in the solution was determined by inductively coupled plasmaatomic emission spectrometry (Perkin Elmer ICP-AES Optima 7300DV).

\section{Potential Ecological Risk Assessment}

With the soil contamination data in the four soil samples, the potential ecological risk index (ERI) 
Table 1. Selected physico-chemical soil properties.

\begin{tabular}{|c|c|c|c|c|c|}
\hline Soils & $\mathrm{pH}$ & Electrical conductivity $(\mu \mathrm{s} / \mathrm{cm})$ & $\mathrm{CaCO}_{3}(\%)$ & $\mathrm{CEC}$ & Organic carbon $(\mathrm{g} / \mathrm{kg})$ \\
\hline E1 & 9.66 & 344 & 36 & 11.82 & 3.07 \\
\hline E2 & 8.78 & 885 & 51.98 & 11.98 & 3.11 \\
\hline E3 & 7.84 & 921 & 37.11 & 10.45 & 3.75 \\
\hline E4 & 9.66 & 910 & 31.45 & 11.02 & 2.98 \\
\hline Average & 8.985 & 765 & 39.135 & 11.3175 & 3.2275 \\
\hline
\end{tabular}

was calculated. ERI represents the sensitivity of the biological community to toxic substances and shows the potential ecological risk caused by overall contamination [24]. The equation used for calculating ERI [25] is:

$$
E R I=\sum_{i=1}^{n} E_{r}^{i}=\sum_{i=1}^{n} T_{r}^{i} \times C_{f}^{i}=\sum_{i=1}^{n}\left(T_{r}^{i} \times \frac{C^{i}}{C_{n}^{i}}\right)
$$

...where: $E_{r}{ }^{i}$ is the monomial potential ecological risk index of the heavy metals, $T_{r}^{i}$ is the toxic response factor for a specific heavy metals ${ }^{r}(\mathrm{Cd}=30, \mathrm{Cr}=2, \mathrm{Cu}=5$, $\mathrm{Pb}=5, \mathrm{Ni}=5, \mathrm{Co}=5$ and $\mathrm{Zn}=1), C_{r}^{i}$ is the contamination factor of heavy metals, $C_{n}$ is the content of ETM in the samples $(\mathrm{mg} / \mathrm{kg})$, and $C_{n}{ }^{i}$ is the background value of heavy metals in the study area $(\mathrm{mg} / \mathrm{kg})$.

In this study, soil background values (BV) of the area from Cicchella et al. (2008) [25] were used (Co: 2; Ni: 23; Cd: 0.45; Cr: 10; Cu: 28.50; Pb: 46.50; Zn: $78.0 \mathrm{mg} / \mathrm{kg}$ ). The contamination degrees and the potential ecological risk of a single ETM $\left(E_{r}^{i}\right)$ were classified as low $\left(E_{r}^{i}<40\right)$, moderate $\left(40 \leq E_{r}^{i}<80\right)$, considerable $\left(80 \leq E_{r}{ }^{i}<160\right)$, high $\left(160 \leq E_{r}{ }^{i}<320\right)$ and very high $\left(E_{r}{ }^{i} \geq 320\right)$. The overall ecological risk (ERI) was classified as low $($ ERI $<95)$, moderate $(95 \leq$ ERI $<190)$, high $(190 \leq \mathrm{ERI}<380)$ and very high $(\mathrm{ERI} \geq 380)$ [25].

\section{Statistical Analysis}

The statistical analyses were all carried out using MS Excel 2007. Pearson correlation analyses were made to investigate the relationships between ERI, soil factors $\left(\mathrm{pH}\right.$, electric conductivity, $\mathrm{CaCO}_{3}, \mathrm{CEC}$, organic carbon, total and bioavailable ETM) and ecological parameters of each plot. Statistical significance in this analysis was defined at $\mathrm{P}<0.05$ and $\mathrm{P}<0.01$.

\section{Results and Discussion}

\section{Soil Features of the Four Soil Samples}

All the soils showed good organic matter content and a subalkaline $\mathrm{pH}$ that coincides with the higher carbonate content in these soils, while EC and CEC were high for all soils (Table 1). The particle size distribution according to the textural classes of E1 and E2 show that soils have similar profiles. They are mainly composed of fractions of $2 \mathrm{~mm}-500 \mu \mathrm{m}$ and $500 \mu \mathrm{m}-200 \mu \mathrm{m}$. They are sandy loam. The particle size distribution according to textural classes E1 and E2 shows that soils have similar profiles and are mostly composed of fractions of $2 \mathrm{~mm}-500 \mu \mathrm{m}$, so they are sandy clay.

Analytical results of the heavy metal concentrations of the investigated soil samples (E1, E2, E3 and E4) were summarized in Table 2. From these results, we note that soil lead $(\mathrm{Pb})$ concentrations ranged from $564.78 \mathrm{mg} / \mathrm{kg}$ to over $691.11 \mathrm{mg} / \mathrm{kg}$ and exceeded the European screening values (ESV) $(100 \mathrm{mg} / \mathrm{kg})$ in all cases (Fig. 1a), which is proof that the road traffic and emission of fumes caused by cars have an impact

Table 2. Heavy metal concentrations ( $\mathrm{mg} / \mathrm{kg}$ ) and ERI of soils samples (E1, E2, E3 and E4).

\begin{tabular}{|c|c|c|c|c|}
\hline & E1 & E2 & E3 & E4 \\
\hline $\mathrm{Pb}(\mathrm{mg} / \mathrm{kg})$ & 628.67 & 691.11 & 670 & 964.78 \\
\hline $\mathrm{Cr}(\mathrm{mg} / \mathrm{kg})$ & 232.3 & 00 & 0.475 & 67.575 \\
\hline $\mathrm{Cu}(\mathrm{mg} / \mathrm{kg})$ & 67.675 & 156.425 & 2.45 & 1.65 \\
\hline $\mathrm{Cd}(\mathrm{mg} / \mathrm{kg})$ & 3.925 & 1.75 & 5.4 & 125.225 \\
\hline $\mathrm{Zn}(\mathrm{mg} / \mathrm{kg})$ & 109.825 & 94.025 & 23.375 & 18.87 \\
\hline $\mathrm{Ni}(\mathrm{mg} / \mathrm{kg})$ & 19.25 & 20.05 & 24.92 & 21.27 \\
\hline $\mathrm{Co}(\mathrm{mg} / \mathrm{kg})$ & 26.475 & 24.175 & 324.59 & 259.99 \\
\hline $\mathrm{ERI}$ & 612.60 & 284.42 & & \\
\hline
\end{tabular}


on the soil content of lead. Soil Cd concentrations ranged from $1.65 \mathrm{mg} / \mathrm{kg}$ to $3.92 \mathrm{mg} / \mathrm{kg}$ and were above ESV (2 mg/kg) in $50 \%$ of cases (Fig. 1f). Soil $\mathrm{Cr}$ concentrations ranged from 00 to $232.3 \mathrm{mg} / \mathrm{kg}$ and exceeded ESV (150 $\mathrm{mg} / \mathrm{kg})$ in $25 \%$ of cases (Fig. 1b). Soil $\mathrm{Cu}$ concentrations ranged from $0.47 \mathrm{mg} / \mathrm{kg}$ to $156.42 \mathrm{mg} / \mathrm{kg}$ and exceeded ESV (120 mg/kg) in $25 \%$ of cases (Fig. 1c), and soil Ni, Co and $\mathrm{Zn}$ concentrations were lower than ESV for sites (Ni: $30 \mathrm{mg} / \mathrm{kg}$; Co: $20 \mathrm{mg} \mathrm{kg}$; Zn: $150 \mathrm{mg} / \mathrm{kg}$ ) in all the soils due to the very high concentrations of some heavy metals (mainly $\mathrm{Pb}$ and $\mathrm{Cd}$ ). The ERI of the four soil samples proved to be high in all cases. This pollution originates from the fact that the soils studied are located on roads and near the quarries by the use of rock. Traffic consists of a contribution by the circulation of vehicles and the equipment of the road [26]. In addition to the flow rate of traffic, another factor that affects the accumulation of pollutants in soil near the roads is the weather and long dry periods, as well as duration and intensity of sediments. All of the above factors may have contributed to the high concentrations
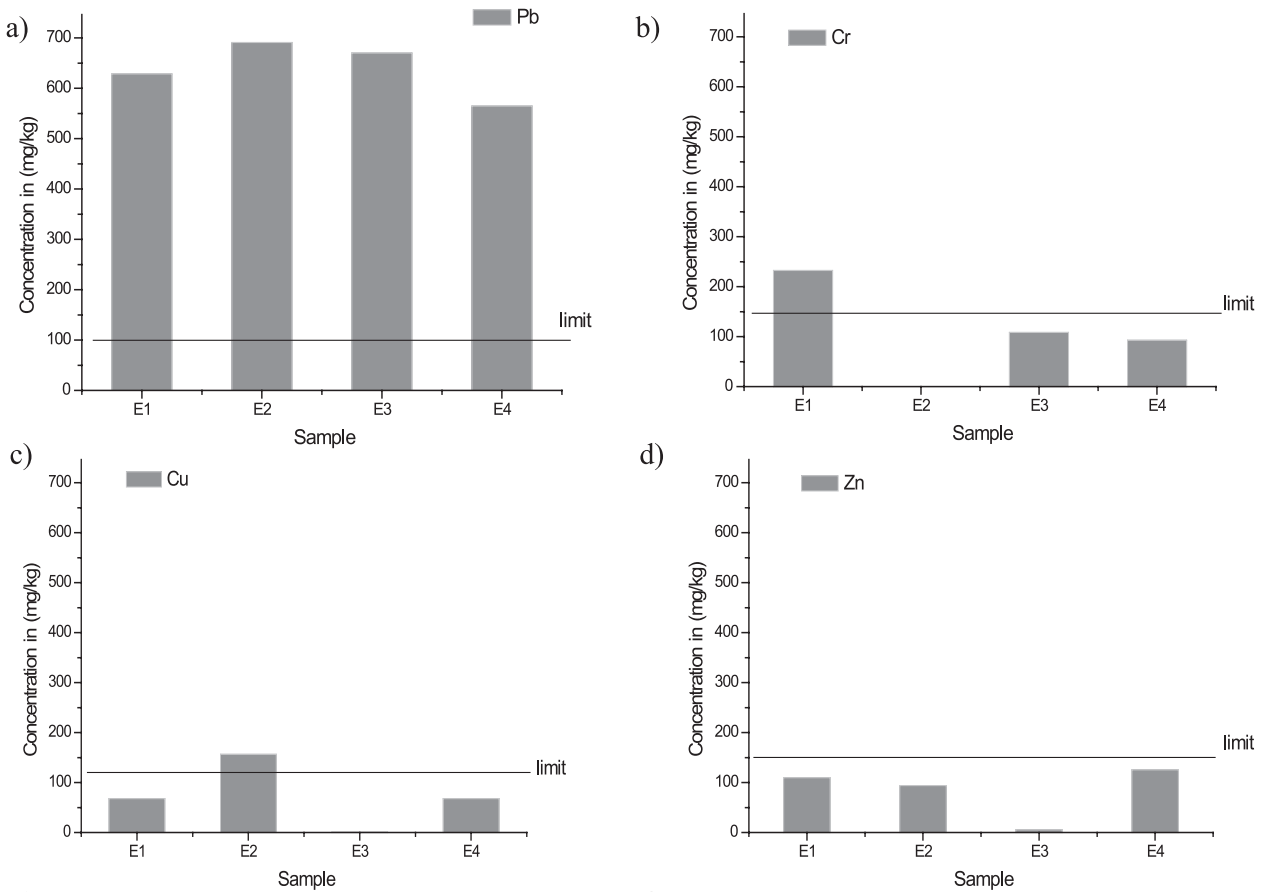

d)
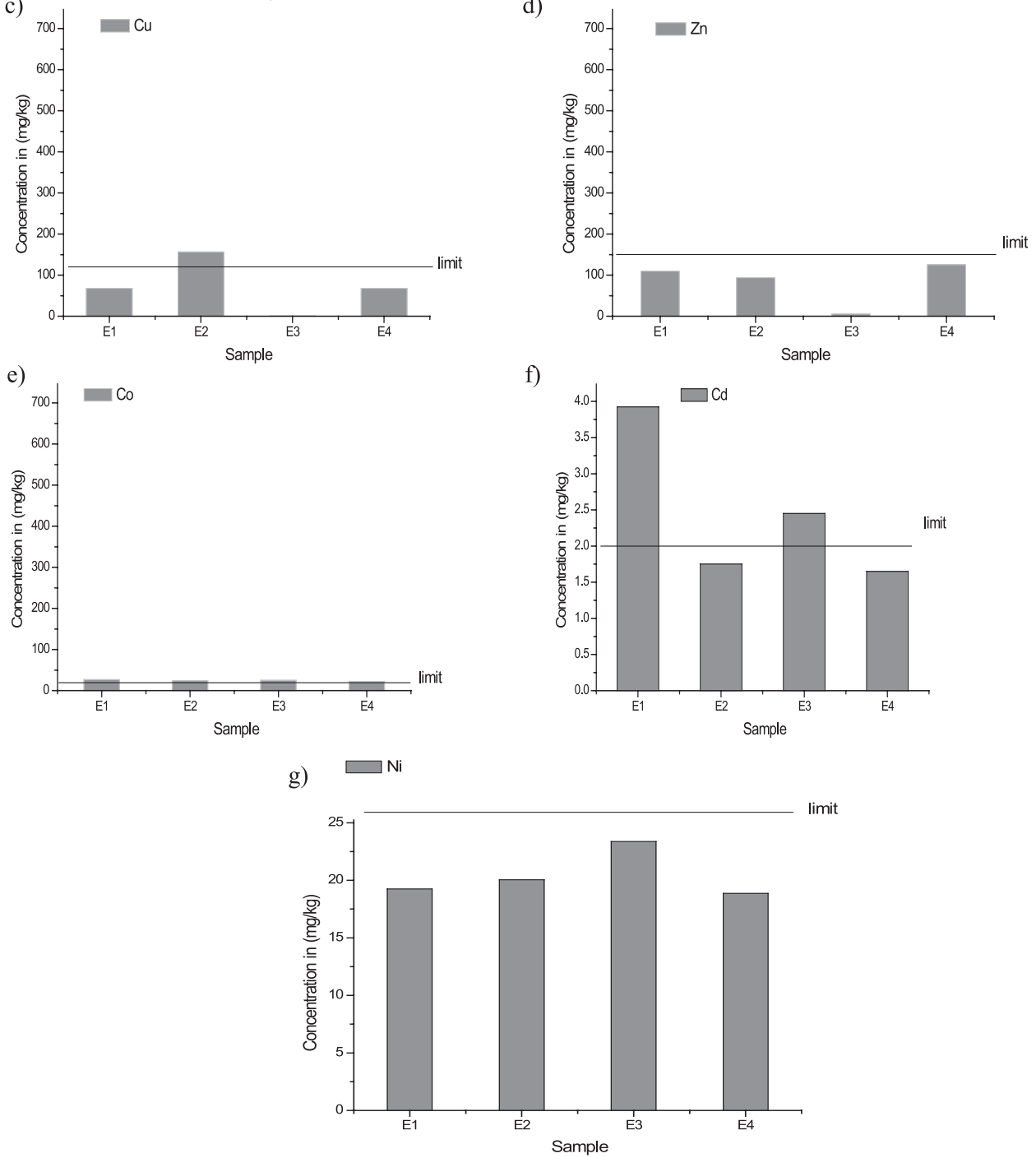

Fig. 1. Total concentrations (mg/kg) of heavy metals in soils samples: a) $\mathrm{Pb}, \mathrm{b}$ ) $\mathrm{Cr}, \mathrm{c}) \mathrm{Cu}$, d) $\mathrm{Zn}$, e) $\mathrm{Co}, \mathrm{f}) \mathrm{Cd}, \mathrm{g}) \mathrm{Ni}$. 
of trace elements detected along the Tlemcen-Sidi bel abbes road. In the case of lead $(\mathrm{Pb})$, the most studied metal made its notable presence in gasoline.

\section{Variations in Heavy-Metal Forms in Soils}

In Fig. 2, the contents of heavy metals vary from one fraction to another and are distributed as follows:

\section{Cadmium}

The results showed that $\mathrm{Cd}$ is essentially carbonatebound with a maximum of $6.85 \mathrm{mg} / \mathrm{kg}$ for soil $\mathrm{S} 1$, $1.95 \mathrm{mg} / \mathrm{kg}$ for soil E4, 1.8 for soil E3 and $1.5 \mathrm{mg} / \mathrm{kg}$ for soil E2. These results also indicate that a significant proportion of cadmium is fixed by the residual phase with a maximum of $0.275 \mathrm{mg} / \mathrm{kg}$ for soil E1, $2.03 \mathrm{mg} / \mathrm{kg}$ for soil E2, $3.44 \mathrm{mg} / \mathrm{kg}$ for soil E3 and $3 \mathrm{mg} / \mathrm{kg}$ for soil E4, which represents more than $50 \%$ in the acid-soluble phase of potentially mobilizable cadmium.

The ranking of the different fractions of $\mathrm{Cd}$ in order of predominance can be as follows:

Carbonates $>$ Residual $>$ Reducible $>$ Oxidizable in descending order for soils E1, E2, E3 and E4. The numerous studies present in the literature preferentially associate cadmium with the carbonate fraction, the exchangeable fraction and the residual phase [27].

The total cadmium content contained in the different phases slightly exceeds the limits $(20 \mathrm{mg} / \mathrm{kg})$, so there is a slight cadmium pollution of the soil; it appears that a significant proportion of this pollution is theoretically leachable, because it is not associated with the residual phase.

\section{Cobalt}

Cobalt exhibited similar behavior in all four phases over the years, ranging from $7.652 \mathrm{mg} /$ $\mathrm{kg}$ to $20.15 \mathrm{mg} / \mathrm{kg}$ for soil $\mathrm{E} 1$, from $8.13 \mathrm{mg} / \mathrm{kg}$ to $14.97 \mathrm{mg} / \mathrm{kg}$ for soil E2 and from $8.097 \mathrm{mg} / \mathrm{kg}$ to $19.66 \mathrm{mg} / \mathrm{kg}$ for soil $\mathrm{E} 3$; the range was from $8.76 \mathrm{mg} / \mathrm{kg}$ to $15.73 \mathrm{mg} / \mathrm{kg}$ for soil E4 in the reducible phase. Its relative share is lower in the residual phase, ranging from $1.33 \mathrm{mg} / \mathrm{kg}$ to $55.77 \mathrm{mg} / \mathrm{kg}$ for soil E1, from $11.02 \mathrm{mg} / \mathrm{kg}$ to $22.63 \mathrm{mg} / \mathrm{kg}$ for soil $\mathrm{S} 2$, from $11.41 \mathrm{mg} / \mathrm{kg}$ to $18.21 \mathrm{mg} / \mathrm{kg}$ for soil E3 and from $18.2 \mathrm{mg} / \mathrm{kg}$ to $21 \mathrm{mg} / \mathrm{kg}$ for soil E4.

These results confirm the low mobility of cobalt. The ranking of the phases in descending order is as follows:

Reducible $>$ Residual $>$ Oxidisable $>$ Acid-extractable . Several authors [27] have underlined this result. a)

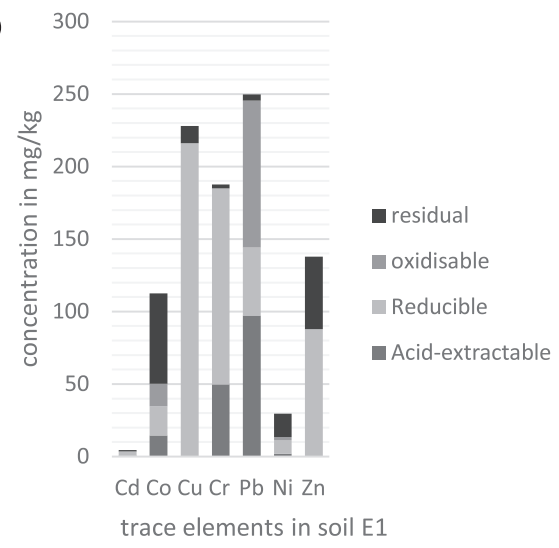

c)

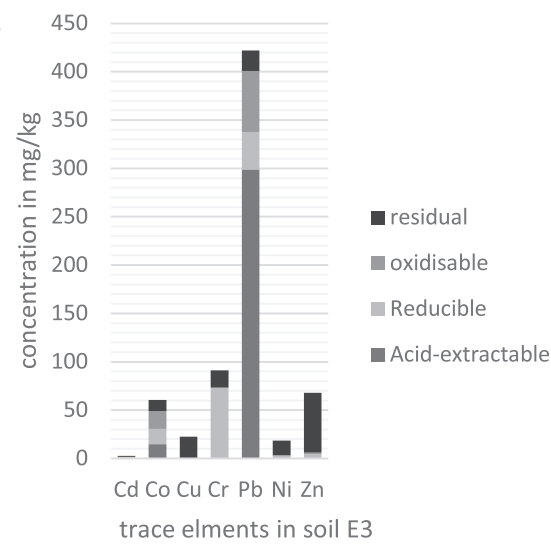

b)

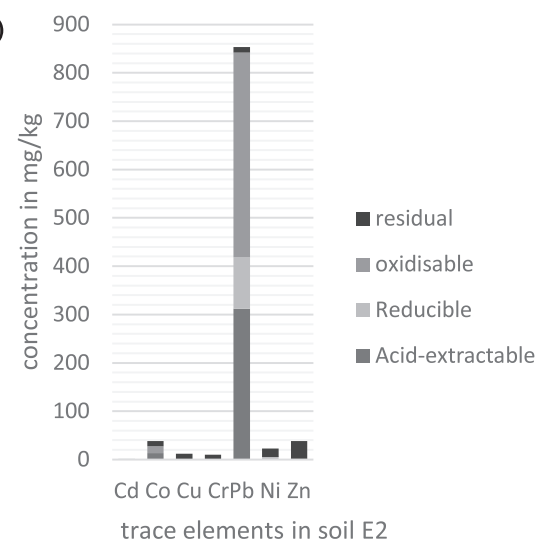

d)

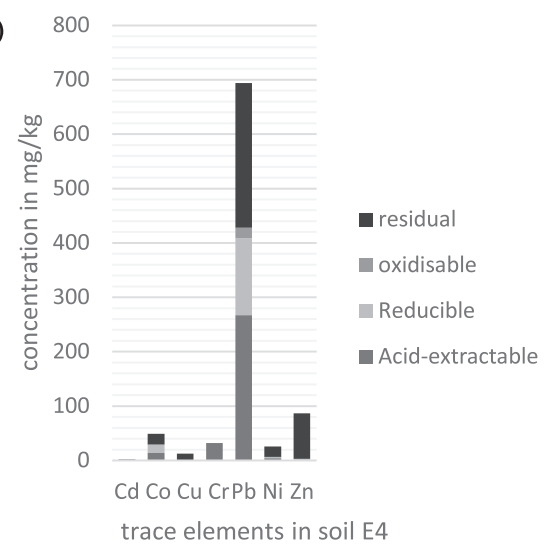

Fig. 2. Distribution of trace element contents $(\mathrm{mg} / \mathrm{kg})$ in soil samples (E1, E2, E3 and E4) in the different fractions (sequential extraction). 
The total levels of Co contained in the different phases exceed the limits of the standards. Soil contamination is reported.

\section{Copper}

The results of the sequential extractions show that $\mathrm{Cu}$ is very little exchangeable and located mainly in organic matter (with a maximum of $7.10 \mathrm{mg} / \mathrm{kg}$ for soil $\mathrm{S} 1,11.98 \mathrm{mg} / \mathrm{kg}$ for soil E2 and $17.90 \mathrm{mg} / \mathrm{kg}$ for E3 and $10.42 \mathrm{mg} / \mathrm{kg}$ for the E4). Moreover, in the residual fraction the results were $15.67 \mathrm{mg} / \mathrm{kg}$ for soil $\mathrm{E} 1$, $6.51 \mathrm{mg} / \mathrm{kg}$ for soil E2 and $6.01 \mathrm{mg} / \mathrm{kg}$ for soil E3 and $18.87 \mathrm{mg} / \mathrm{kg}$ for soil E4.

From these results obtained, the scale of predominance of $\mathrm{Cu}$ as a function of the chemical phases can be as follows: Organicmatter $>$ Residual $>$ Oxides of Manganese and Iron $>$ Carbonates.

Several authors [28] who associate $\mathrm{Cu}$ with organic matter, iron oxides, manganese oxides and carbonates have recorded this affinity for the oxidisable fraction. The first two fractions (the oxidisable fraction and the reducible fraction) have generally normal values for all soils E1, E2, E3 and E4. The total $\mathrm{Cu}$ content contained in the different phases is below the limits of the standards. We conclude that copper does not contaminate these soils.

\section{Nickel}

$\mathrm{Ni}$ is mainly bound to the reducible phase with a maximum of $17.95 \mathrm{mg} / \mathrm{kg}$ for soil $\mathrm{S} 1,13.93 \mathrm{mg} / \mathrm{kg}$ for soil E2, $11.50 \mathrm{mg} / \mathrm{kg}$ for soil E3 and $10.78 \mathrm{mg} / \mathrm{kg}$ for soil E4. It is also present in the residual phase, but its content varies from soil to soil with a maximum of $19.66 \mathrm{mg} / \mathrm{kg}$ for soil $\mathrm{S} 1,17.67 \mathrm{mg} / \mathrm{kg}$ for soil E2, 15.15 $\mathrm{mg} / \mathrm{kg}$ for soil E3 and $30.48 \mathrm{mg} / \mathrm{kg}$ for soil E4, so nickel is considered as a little mobile element. $\mathrm{Ni}$ is very preferentially exchangeable.

The ranking of the phases in order of importance is as follows: Oxides of iron and manganese $>$ Residual $>$ Carbonate Materials $>$ Organic.

Several works [29-30] have highlighted similar results.

Total Ni content contained in the different phases exceeds the limits of the standards during the year 2017 . A slight contamination due especially to the high levels of $\mathrm{Ni}$ in the reducible phase of the soil was found.

\section{Chrome}

$\mathrm{Cr}$ is mainly concentrated in the oxidisable phase with a maximum of $227.96 \mathrm{mg} / \mathrm{kg}$ for soil E1, $24.59 \mathrm{mg} / \mathrm{kg}$ for soil E2, $47.29 \mathrm{mg} / \mathrm{kg}$ for soil E3 and $26.28 \mathrm{mg} / \mathrm{kg}$ for soil E4.

For soil $\mathrm{S} 1, \mathrm{Cr}$ is weak and exchangeably distributed between $00 \mathrm{mg} / \mathrm{kg}$ and $71.95 \mathrm{mg} / \mathrm{kg}, 12.33 \mathrm{mg} / \mathrm{kg}$, $97.18 \mathrm{mg} / \mathrm{kg}$ and $30.375 \mathrm{mg} / \mathrm{kg}$ for successive soils $\mathrm{S} 1$, $\mathrm{S} 2, \mathrm{~S} 3$ and S4. We also noticed that reducible phase contents are negligible. These results reflect an average mobility of $\mathrm{Cr}$.

The ranking in descending order of the phases is as follows: Oxide $>$ Residual $>$ Carbonates $>$ Reducible.

The total levels of $\mathrm{Cr}$ contained in the different phases during the year 2017 are below the limits, and it can be said that the soils studied do not show contamination by chromium.

\section{Zinc}

The results of the sequential extractions show that zinc is very little exchangeable. In addition, a large fraction of Zinc is related to the residual fraction with a maximum (of $597.55 \mathrm{mg} / \mathrm{kg}$ for the soil $\mathrm{S} 1$, $448.21 \mathrm{mg} / \mathrm{kg}$ for the soil E2, $62 \mathrm{mg} / \mathrm{kg}$ for soil S3 and $95 \mathrm{mg} / \mathrm{kg}$ for soil E4) in the year 2017.

In fact, the ranking of the phases in order of importance is as follows: Reducible $>$ Residual $>$ Carbonat es $>$ Organic Materials.

Several works have evidenced similar results [29, 30].

Zinc is among the metals studied, one with high levels in the reducible phase reaching maxima of $87.83 \mathrm{mg} / \mathrm{kg}$ for soil E1, $3.98 \mathrm{mg} / \mathrm{kg}$ for soil E2, $2.73 \mathrm{mg} / \mathrm{kg}$ for soil E3 and $10.78 \mathrm{mg} / \mathrm{kg}$ for soil E4. And also low levels of $\mathrm{Zn}$ in the extractable fraction with a maximum of $1.31 \mathrm{mg} / \mathrm{kg}$ for soil $\mathrm{E} 1,1.3 \mathrm{mg} / \mathrm{kg}$ for soil E2, $1.5 \mathrm{mg} / \mathrm{kg}$ for soil E3 and $0.6 \mathrm{mg} / \mathrm{kg}$ for soil E4, which induces low mobility.

The total contents of $\mathrm{Zn}$ contained in the different phases do not exceed the limits, which corresponds to no significant soil contamination over time by zinc, except that soil E1 contamination is detected.

\section{Lead}

The analysis of the results shows, on the one hand, that $\mathrm{Pb}$ is preferentially bound to the acid-soluble fraction (with a maximum of $293.25 \mathrm{mg} / \mathrm{kg}$ for soil $\mathrm{E} 1,312 \mathrm{mg} / \mathrm{kg}$ for soil S2, $439.75 \mathrm{mg} / \mathrm{kg}$ for soil E3 and $263.75 \mathrm{mg} / \mathrm{kg}$ for soil E4), followed by the reducible fraction (204.58 mg.kg for soil E1, $200 \mathrm{mg} / \mathrm{kg}$ for soil E2, $207.22 \mathrm{mg} / \mathrm{kg}$ for soil E3 and $198.75 \mathrm{mg} / \mathrm{kg}$ for soil E4). On the other hand, it is very weakly adsorbed by the oxidizable fraction for the four soils. According to its results, lead is potentially not very mobile.

The ranking of the phases in order of importance can be presented as follows: Acid-soluble $>$ Reducible $>R$ esidual $>$ Oxidisable.

We preferentially associate lead with the reducible fraction [31] then with the acid-soluble fraction. The total $\mathrm{Pb}$ levels in the different phases of the highest soils E1, E2, E3 and E4 are reported. In fact, the Pb contents for the first two fractions (reducible and carbonates) are stronger than the other fractions. The total contents of $\mathrm{Pb}$ contained in the different phases exceed the limits of the standards. Acute contamination 
Table 3. Mean values of ecological risk factor $\left(E_{r}^{i}\right)$ and potential ecological risk index (ERI) in the different soil samples (E1, E2, E3 and E4).

\begin{tabular}{|c|c|c|c|c|c|c|c|c|}
\hline \multicolumn{8}{|c|}{$E_{r}^{i}$} & \multirow{2}{*}{ ERI } \\
\hline & $\mathrm{Pb}$ & $\mathrm{Cr}$ & $\mathrm{Cu}$ & $\mathrm{Cd}$ & $\mathrm{Zn}$ & $\mathrm{Ni}$ & Co & \\
\hline E1 & 67.59 & 46.46 & 11.87 & 261.66 & 154.63 & 4.1847 & 66.18 & 612.60 \\
\hline E2 & 74.31 & 0 & 27.44 & 116.66 & 1.20 & 4.35 & 60.43 & 284.42 \\
\hline E3 & 72.043 & 21.68 & 0.08 & 163.33 & 0.06 & 5.08 & 62.3 & 324.59 \\
\hline E4 & 60.72 & 18.51 & 11.87 & 110 & 1.60 & 4.10 & 53.17 & 259.99 \\
\hline Average & 68.67 & 21.66 & 12.81 & 162.91 & 39.37 & 4.43 & 60.52 & 370.40 \\
\hline
\end{tabular}

- especially due to high levels of $\mathrm{Pb}$ in the reducible phase and carbonates of soils - is found. Moreover, the total of the concentrations of the ETM obtained from the results of the different fractions confirms the $\mathrm{Pb}$, $\mathrm{Cd}$ and $\mathrm{Cu}$ pollution found by simple extraction (aqua regia), but reveals the existence of $\mathrm{Ni}$ pollution. This result is perhaps due to its mobility in a basic soil.

Nevertheless, extraction with the calcium chloride solution aims to quantify the mobile fraction, that is to say the fraction of bioavailable elements and easily leachable with water. This extraction best represents the intrinsic conditions of the soil solution at equilibrium in terms of ionic strength. It is often used to establish soil-plant correlations and thus define the bioavailable fraction of pollution.

From these results (Table 4), we note that:

- $\mathrm{Cd}, \mathrm{Cu}$ and $\mathrm{Ni}$ are highly bioavailable and therefore will be easily absorbed by food plants, potentially causing a health risk.

- $\mathrm{Pb}$ is moderately bioavailable.

- $\mathrm{Cr}$ and $\mathrm{Zn}$ are poorly bioavailable.

- Co has no bioavailability.

\section{Correlation Matrix (CM)}

Inter-element relationships in the soil matrix provide information on the sources of heavy metals and pathways in the geo environment. In general, the correlations between the metals were in agreement with the results obtained, and the CM was useful for confirming some new associations between metals that had not been clearly started in the previous analysis. From Pearson correlation coefficient values (Table 5), a significant positive correlation $(\mathrm{p}<0.01)$ exists between cadmium and nickel ( $\mathrm{r}=0.96, \mathrm{p}<0.01), \mathrm{Cu}(\mathrm{r}=0.69$, $\mathrm{p}<0.01), \mathrm{Pb}(\mathrm{r}=0.95, \mathrm{p}<0.01)$ and $\mathrm{Zn}(\mathrm{r}=0.98)$.

Cobalt shows a positive correlation to be relatively weak with $\mathrm{Cu}(\mathrm{r}=0.87)$, and between $\mathrm{Pb}(\mathrm{r}=0.4)$ and $\mathrm{Zn}(\mathrm{r}=0.98)$, Ni $(\mathrm{r}=0.7)$ was also found by Cai et al. (2012, $\mathrm{r}=0.60)$ [32] and Mi et al. (2015, $\mathrm{r}=0.81$ ) [33], and $\mathrm{Zn}(\mathrm{r}=0.98)$ and lead $(\mathrm{Pb})$ is significantly correlated with $\mathrm{Ni}$ ( $\mathrm{r}$ and $\mathrm{Zn}$ and $\mathrm{Cu}$ is correlated with $\mathrm{Cr}$ $(\mathrm{r}=0.95, \mathrm{p}<0.01)$, Ni $(\mathrm{r}=0.28, \mathrm{p}<0.01)$ and $\mathrm{Zn}(\mathrm{r}=078$, $\mathrm{p}<0.01, \mathrm{Cr}$ is positively correlated with $\mathrm{Pb}(\mathrm{r}=0.63)$, $\mathrm{Zn}(\mathrm{r}=0.76)$ and $\mathrm{Ni}(\mathrm{r}=0.86)$. The strong correlation between the elements indicates their common origin [34], in particular that of carbonates and sulphides (sphalerite, strontianite, galena, etc.). The significant positive correlation of $\mathrm{Cd}, \mathrm{Cr}, \mathrm{Pb}, \mathrm{Co}, \mathrm{Zn}$ and $\mathrm{Ni}$ indicates that the elements are derived from similar materials, particularly coalmines in underground mining activities [35].

A significant weak correlation exists between soil $\mathrm{pH}$ and $\mathrm{Cd}(\mathrm{r}=0.78), \mathrm{Co}(\mathrm{r}=0.77), \mathrm{Cu}(\mathrm{r}=0.96), \mathrm{Cu}$ $(\mathrm{r}=0.91)$ and $\mathrm{Pb}(\mathrm{r}=0.28)$. In addition, there is no significant correlation between soil $\mathrm{pH}$, and $\mathrm{Ni}$ and $\mathrm{Zn}$ were observed for the analyzed soils, which is consistent with those obtained by Tume et al. [35] for the natural surface soils of Catalonia, Spain. As characterized by a similar range of $\mathrm{pH}$ values and by Manta et al. [35], TC and CEC show strong positive correlations with all heavy metals.

Organic matter show strong positive correlations with TC\% ( $r=0.98)$, CEC ( $r=0.28), \mathrm{Cd}(\mathrm{r}=0.95)$, Co $(\mathrm{r}=0.67), \mathrm{Cu}(\mathrm{r}=0.76), \mathrm{Cr}(\mathrm{r}=0.97), \mathrm{Pb}(\mathrm{r}=0.48)$. As we noted, there is no significant correlation between $\mathrm{Ni}$ an $\mathrm{Zn}$. ERI also shows strong positive correlation with $\mathrm{pb}, \mathrm{Zn}, \mathrm{Ni}$ and $\mathrm{pH}$ water, $\sigma, \mathrm{TC} \%, \mathrm{CEC}$, and organic matter while showing a weak or almost non-existent correlation with $\mathrm{Cd}, \mathrm{Cr}, \mathrm{Co}$ and $\mathrm{Cu}$. This confirms the results obtained.

Table 4. Trace elements content $(\mathrm{mg} / \mathrm{kg})$ in soil samples extracted with $\mathrm{CaCl}_{2}$.

\begin{tabular}{|c|c|c|c|c|}
\hline & E1 & E2 & E3 & E4 \\
\hline $\mathrm{Pb}$ & 28.775 & 25 & 27.15 & 23.4 \\
\hline $\mathrm{Cr}$ & 00 & 0.27 & 4,25 & 0,90 \\
\hline $\mathrm{Cu}$ & 16.63 & 101.63 & 59.15 & 108.83 \\
\hline $\mathrm{Zn}$ & 3.25 & 1.28 & 0.50 & 2.88 \\
\hline $\mathrm{Ni}$ & 7.225 & 10.375 & 7.125 & 22.075 \\
\hline $\mathrm{Co}$ & 9.125 & 9.2 & 8.6 & 9.55 \\
\hline $\mathrm{Cd}$ & 1.58 & 1.45 & 1.80 & 3.53 \\
\hline Average & 8.175 & 9.7875 & 7.8625 & 15.8125 \\
\hline
\end{tabular}


Table 5. Correlation matrix between different heavy metals and physico-chemical properties for soils samples.

\begin{tabular}{|c|c|c|c|c|c|c|c|c|c|c|c|c|c|}
\hline & $\mathrm{Cd}$ & Co & $\mathrm{Cu}$ & $\mathrm{Cr}$ & $\mathrm{Pb}$ & $\mathrm{Ni}$ & $\mathrm{Zn}$ & $\begin{array}{c}\mathrm{pH} \\
\text { water }\end{array}$ & $\boldsymbol{\sigma}$ & $\mathrm{TC} \%$ & CEC & $\begin{array}{l}\text { Organic matter } \\
\text { g. } \mathrm{kg}^{-1}\end{array}$ & ERI \\
\hline $\mathrm{Cd}$ & 1 & & & & & & & & & & & & \\
\hline Co & 0.16 & 1 & & & & & & & & & & & \\
\hline $\mathrm{Cu}$ & 0.69 & 0.87 & 1 & & & & & & & & & & \\
\hline $\mathrm{Cr}$ & 0.09 & 0.47 & 0.95 & 1 & & & & & & & & & \\
\hline $\mathrm{Pb}$ & 0.95 & 0.4 & 0.02 & 0.63 & 1 & & & & & & & & \\
\hline $\mathrm{Ni}$ & 0.96 & 0.7 & 0.28 & 0.86 & 0.41 & 1 & & & & & & & \\
\hline $\mathrm{Zn}$ & 0.98 & 0.66 & 0.76 & 0.9 & 0.41 & 0.01 & 1 & & & & & & \\
\hline $\mathrm{pH}$ eau & 0.78 & 0.77 & 0.96 & 0.61 & 0.28 & 0.03 & 0.04 & 1 & & & & & \\
\hline$\sigma$ & 0.07 & 0.3 & 0.16 & 0.16 & 0.9 & 0.6 & 0.64 & 0.46 & 1 & & & & \\
\hline TC $\%$ & 0.73 & 0.76 & 0.73 & 0.34 & 0.18 & 0.91 & 0.92 & 0.67 & 0.25 & 1 & & & \\
\hline CEC & 0.77 & 0.7 & 0.91 & 0.97 & 0.79 & 0.33 & 0.34 & 0.46 & 0.46 & 0.42 & 1 & & \\
\hline Organic carbon g. $\mathrm{kg}^{-1}$ & 0.95 & 0.67 & 0.76 & 0.97 & 0.48 & nd & nd & 0.07 & 0.07 & 0.98 & 0.29 & 1 & \\
\hline ERI & 0.01 & 0.21 & 0.07 & 0.12 & 0.99 & 0.78 & 0.83 & 0.62 & 0.62 & 0.78 & 0.6 & 0.85 & 1 \\
\hline
\end{tabular}

\section{Conclusions}

This study analyzed the concentrations and forms of heavy metals in agricultural soil beside a road in western Algeria. The total concentrations of $\mathrm{Pb}, \mathrm{Co}, \mathrm{Cd}$, $\mathrm{Cr}$ and $\mathrm{Cu}$ exceeded the background values in $75 \%$ of cases.

The level of contamination of heavy metals in these soils studied strongly depended on the traffic volume and the atmospheric dispersion resulting from traffic rotation. The frequency of the use of brakes is an additional factor that influenced the levels of contamination. The concrete highway had higher levels of contamination, and vehicle speeds also contributed significantly to the degree of contamination of heavy metals.

Our results show that these metals $(\mathrm{Pb}, \mathrm{Cu}$ and $\mathrm{Zn})$ are mainly present in the residual fraction. This supports the hypothesis that $\mathrm{Cu}, \mathrm{Pb}$ and $\mathrm{Zn}$ are less bioavailable in the soils examined. $\mathrm{Cd}$ and $\mathrm{Ni}$ are highly bioavailable and therefore will be easily absorbed by food plants, potentially causing health risks. The results show that there is a significant correlation between heavy metals, and this is evidence of their common origin. $\mathrm{pH}$, carbonate ratio, $\mathrm{CEC}$ and the amount of organic matter have a significant impact on concentrations of heavy metals in agricultural soil.

\section{Acknowledgements}

This work was done at the Laboratory of Environmental and Inorganic Chemistry at Tlemcen University. We would like to thank everyone who helped us in this research. We have tried hard to obtain satisfactory results, new and qualitative. We hope that researchers will benefit from this paper.

\section{Conflict of Interest}

The authors declare no conflict of interest.

\section{References}

1. MASSA I., KALIVAS D., EHALIOTIS C., GASPARATOS D. Total and available heavy metal concentrations in soils of the Thriassio plain (Greece) and assessment of soil pollution indexes. Environmental Monitoring and Assessment. 185 (8), 6752, 2013.

2. KANAT G., IKIZOGLU B., ERGUVEN G.O., BERIVAN A. Determination of Pollution and Heavy Metal Fractions in Golden Horn Sediment Sludge (Istanbul, Turkey). Pol. J. Environ. Stud. 27 (6), 2606, 2018.

3. BABA AHMED A., BOUHADJERA K. Assessment of metals accumulated in Durum wheat (Triticum durum Desf.). Pepper (Capsicum annuum) and agricultural soils. Afr. J. Agr. Res. 5 (20), 2796, 2010.

4. QIAO M., CAI C., HUANGY Y., LIU Y., LIN A., ZHENG Y. Characterization of soil heavy metal contamination and potential health risk in metropolitan region of northern China. Environmental Monitoring and Assessment. 172 (1-4), 354, 2011

5. MODRZEWSK B., WYSZKOWSKI M. Trace metals content in soils along the state road 51 (northeastern Poland). Environ. Monit. Assess. 186 (4), 2590, 2014

6. LINHUA S., SONGBAO F. Heavy Metals in the Surface Soil around a Coalmine: Pollution Assessment and Source Identification. Pol. J. Environ. Stud. Vol. 28 (4), 2718, 2019.

7. YOUSFI R., EL OUEAR Z., DAHRI N., OUDDANE B., RIGANE H. Evaluating the Heavy MetalsAssociated Ecological Risks in Soil and Sediments of a 
Decommissioned Tunisian Mine. Pol. J. Environ. Stud. 28 (4), 2982, 2019.

8. LEE T.D., BYEONG-KYE T.T. Determining contamination level of heavy metals in road dust from busy traffic. J. Environ. Manage. 3 (92), 555, 2011.

9. SUN Y. Ecological Risk Evaluation of Heavy Metal Pollution in Soil Based on Simulation. Pol. J. Environ. Stud. 26 (4), 1694, 2017.

10. WEI X., GAO B., WANG P., ZHOU H., LU J. Pollution characteristics and health risk assessment of heavy metals in street dusts from different functional areas in Beijing, China. Ecotoxicol. Environ. Saf. 112, 187, 2015.

11. LI X., POON C.S., LIU P. S. Heavy metal contamination of urban soils and street dusts in Hong Kong. Appl. Geochem. 16, 1362, 2001.

12. SHABBAJ I.I., ALGHAMDIL M.A., SHAMY M., HASSAN S.K., ALSHARIF M.M., KHODER M.I. Risk Assessment and Implication of Human Exposureto Road Dust Heavy Metals in Jeddah, Saudi Arabia. Inter. J. Envir. Res.Pub. Hea. 15(1), 36, 2017

13. LUI Q., LIU Y., ZHANG M. Mercury and cadmium contamination in traffic soil of Beijing, China. Bulletin of Environmental Contamination and Toxicology. 88, 155, 2012 .

14. CHRISTOFORIDIS A., STAMATIS N. Heavy metal contamination in street dust and roadside soil along the major national road in Kavala's region. Greece. Geoderma $151(3-4), 258,2009$

15. APEAGYEI E., BANK M.S., SPENGLER J.D. Distribution of heavy metals in road dust along an urban-rural gradient in Massachusetts. Atmos. Environ. 45, 2311, 2011.

16. LUO X.S., YU S., ZHU Y.G., LI X.D. Trace metal contamination in urban soil of China. Sci. Total Environ. 422, 17, 2012

17. HWANGA H.M., FIALAAL M.J., PARKB D. Review of pollutants in urban road dust and storm water runoff: part 1. Heavy metals released from vehicles. Intern. J. Urban Sci. 20, 335, 2016 .

18. SEZGIN N., OZCAN H K., DEMIR G., NEMLIOGLU S., BAYAT C. Determination of heavy metal concentrations in street dusts in Istanbul E-5 highway. Environ. Int. 29 (7), 980, 2004 .

19. D'EMILIO M., CAGGIANO R., MACCHIATO M., RAGOSTA M., SABIA S. Soil heavy metal contamination in an industrial area: analysis of the data collected during a decade. Environ. Monit.Assess. 185 (7), 5952. 2012.

20. TASPINAR F., BOZKURT Z. Heavy metal pollution and health risk assessment of road dust on selected highways in Düzce, Turkey, Environmental Forensics. 19(3), 2, 2018.

21. CHEN X., XIA X., ZHAO Y., ZHANG P. Heavy metal concentrations in roadside soils and correlation with urban traffic in Beijing, China. J. Hazard. Mater. 181 (1-3), 641, 2010.
22. HASSAN S.K., KHODER M.I. Chemical characteristics of atmospheric PM2.5 loads during air pollution episodesin Giza, Egypt. Atmos. Environ. 150, 347, 2017.

23. SU X., ZHU J., FU Q., ZUO J., LIU Y., HU H. Immobilization of lead in anthropogenic contaminated soils using phosphates with/without oxalic acid. J. Environ. 28, 66, 2015

24. ZHAO H., LI X. Risk assessment of metals in roaddeposited sediment along an urban-rural gradient. Environ. Pollut. 174, 298, 2013.

25. VISCONTI D., FIORENTINO N., STINCA A., DI MOLA I., FAGNANO M. Use of the native vascular flora for risk assessment and management of an industrial contaminated soil. Itali. J. Agr. 13, 24, 2018.

26. SALOMON W, MOUK W.G. Processes affecting trace elements in lake. Ijssel. Abstarct.10 ${ }^{\text {th }}$ Int. Cong. Sedi. Jerusalem. 569, 1978

27. ALLOWAY B. Heavy metals in soils. John Wiley \& Sons, 1990.

28. BABA AHMED A. Study of contamination and accumulation of some heavy metals in cereals, vegetables and agricultural soils irrigated by sewage from the hammam town Boughrara. Degree Doc. 124, Algeria, 2012.

29. ABOUBAKER C. Impacts of phosphate discharges concentrating on the distribution of metals heavy soil-plant interface in the region Métlaoui; 85, DEA, 2003.

30. ALGAN O., BALKIS N., NAMIKCAGATAY M., SARI E. The sources of metal contents in the shelf sediments from the Marmara sea. J. Turkey. Environ. Geol. 46, 932, 2004.

31. DONG D., NELSON Y.M., LION L.W., SHULER M.L., GHIORSE W.C. Adsorption of $\mathrm{Pb}$ and $\mathrm{Cd}$ onto metal oxides and organic material in natural surface coatings as determined by selective exactions: new evidence for the importance of $\mathrm{Mn}$ and Fe oxides, J. Wat. Res. 34, 434, 2000.

32. CAI L.M., XU Z.C., REN M.Z., GUO Q.W., HU X.B., HU G.C., WAN H.F., PENG P.A. Source identification of eight hazardous heavy metals in agricultural soils of Huizhou,Guangdong Province, China. Ecotoxicol. Environ. Saf. 78, 2, 2012.

33. MI ZHOU., BIN LIAO., WENSHENG SHU., BING Y.,CHONGYU L. Pollution Assessment and Potential Sources of Heavy Metals in Agricultural Soils around Four $\mathrm{Pb} / \mathrm{Zn}$ Mines of Shaoguan City, China. Soil. Sedim. Contamin: A. Inter. J. 24 (1), 85, 2015.

34. MAIZ I., ARAMBARRI I., GARCIA R., MILLAN Evaluation of heavy metal availability in polluted soils by two sequential extraction procedures using factor analysis. Environ. Pollut. 110 (1), 3, 2000.

35. MOHAMMED A., BHUIYAN H., PARAVEZ L., IIISLAM M.A., SAMUEL B,. Dampare S.S. Heavy metal pollution of coal mine-affected agricultural soil in the northern part of Bangladesh. J. Hazard. Materia. 173, 390, 2010. 
